\title{
The future of business in Visegrad region
}

\author{
Anna Sacio-Szymańska ${ }^{1}$ Anna Kononiuk ${ }^{2} \cdot$ Stefano Tommei $^{3} \cdot$ Ondrej Valenta $^{4}$. \\ Éva Hideg ${ }^{5} \cdot$ Judit Gáspár $^{5} \cdot$ Peter Markovič $^{6} \cdot$ Klaudia Gubová $^{6} \cdot$ Brigita Boorová $^{6}$
}

Received: 22 August 2016/Accepted: 21 November 2016/Published online: 14 December 2016

(C) The Author(s) 2016. This article is published with open access at Springerlink.com

\begin{abstract}
The paper aims to advance Futures Research by outlining the context and development perspectives of business Foresight in Visegrad region (that is in: Poland, Czech Republic, Slovakia and Hungary). Authors apply their research to tackle present challenges associated with the limited awareness of Foresight and constrained access to Foresight training offer in the region, which leads to insufficient Futures Literacy competences among managers and thus stiffens the opportunity to take advantage of Foresight in business practice. The paper presents two perspectives of analyzing business futures. A macro perspective, which concerns possible development scenarios of Visegrad economies, and a micro perspective, which concerns possible development scenarios of individual companies from Visegrad region. The methodology for the macro analyses involves the discussion of the futures of business in Visegrad economies based on quantitative indicators related to trade balance, foreign direct investment and SMEs prevalence analysed over 2002 - 2014 period. Whereas, the results derived from the micro level
\end{abstract}

Electronic supplementary material The online version of this article (doi:10.1007/s40309-016-0103-3) contains supplementary material, which is available to authorized users.

Anna Sacio-Szymańska anna.sacio@itee.radom.pl

1 Institute for Sustainable Technologies - National Research Institute, RadomPułaskiego 6/10, Poland

2 Białystok University of Technology, Białystok, Poland

3 StateStreet Bank GmbH, Kraków, Poland

4 Technology Centre CAS, Prague, Czech Republic

5 Corvinus University of Budapest, Budapest, Hungary

6 University of Economics in Bratislava, Bratislava, Slovakia analysis are based on the expert-based scenario building exercise executed by Visegrad entrepreneurs participating in a 2day international Foresight workshop. The research portrays the results achieved so far in the FOR_V4 project: "Mobilising Corporate Foresight potential among V4 countries", which aims to bring futures knowledge and techniques to managers, who are expected to become "Corporate foresight evangelists" in Visegrad region.

Keywords Corporate foresight · Visegrad region · Futures literacy $\cdot$ Scenario building

\section{Introduction}

Few companies today would say they are happy with the way they plan for an increasingly fluid and turbulent business environment [1].

But at the same time when offered with either Foresight or specifically scenario consulting service, they react with scepticism, and the only pro-Foresight arguments that are not automatically rejected are those of real evidence of effectiveness of futures work, such as examples of accurate predictions, decisions made based on these, profits made or losses avoided. All of them illustrated with explicit company names, which have "succeeded". A good example that still works with management boards (although it's not the latest one) is to explain that Shell "knew" about the increase of the oil price from USD 1.85 to close to USD 30 by the mid- seventies, one or 2 years in advance. And then similarly in 1985, when the price was 27 USD Shell "visited" the world of 16 USD oil, which helped the company a lot in the spring of 1986, when the price was actually 15 USD $[2,3]$.

On the contrary, emphasizing the real value and competitive advantage of individual [1] and institutional learning [2], 
changing mental models that decision makers carry in their heads $[1,4,5]$ and institutional rules [2, 6], stemming from Foresight-aided or scenario planning, does not immediately resonate with the key people in an organisation who have the power to make important decisions.

The above discussion is especially relevant to enterprises operating in Central and Eastern Europe ${ }^{1}$ (CEE) economies. A self-evident argument, which can be used to explain this reluctant point of view towards Foresight is the preference (among CEE-based businesses) given to product and process technological innovations as opposed to organisational innovations [7]. However, the limited approval and low prevalence of Futures Literacy competences among managers or policy makers are not limited to Central and Eastern Europe but they characterize modern society in general as it is described by [8, 9].

This implies from futures researchers and consultants to embrace the following key aims:

(1) To deliver high quality embodied Foresight output, such as: scenarios, roadmaps, visions, options, key priorities or actions, explanations of trends or weak signals etc. $[10,11]$

(2) To enhance disembodied learning processes on individual and organisational levels, which would lead to revising the views of the world $[1,2]$, accepting uncertainty, triggering spontaneity and experimentation, and acting accordingly with/against changes/shocks $[8,9]$.

One of the means to provide the fertile environment to realise this two-fold Foresight mission is to teach the future [12]. Owing to the facts that: diverse foresight educational offer, which includes both: comprehensive, formal university degrees in Futures Studies, and non-formal education courses in Foresight ${ }^{2}$, is not evenly distributed across Europe as well as acknowledging that Futures Literacy [9] is a transversal competence that can be tailored on any entrepreneurial actor, the authors of the paper have chosen to undertake research, which can be summarized as follows:

- The aim of the research is to develop and discuss alternative business futures for Visegrad (V4) region;

- The research is undertaken in the framework of "Mobilizing Corporate Foresight potential among V4 countries (FOR V4)" project [13], which strives to introduce entrepreneurs of the Visegrad countries to Foresight;

\footnotetext{
${ }^{1}$ Central and Eastern Europe, abbreviated CEE, is a generic term for the group of countries in Central Europe, Southeast Europe, Northern Europe, and Eastern Europe, usually meaning former communist states in Europe. Four, among several CEE economies, form the Visegrad Group, namely: Czech Republic, Hungary, Poland and Slovakia.

2 http://www.globalforesight.org/. Accessed 18.11.2016
}

- The authors build on previous research undertaken by [14] and implement a methodological approach, which allows to combine quantitative and qualitative scenario building methods;

- The analyses are in progress until the end of January 2017. and can be monitored on the project website ${ }^{3}$.

The paper is organized as follows: first part discusses the economic features of the Visegard region, second part encompasses literature review and presents the methodology of the research; third part gives the overview of the results with overall summary and conclusions.

\section{The economic features and key challenges of Visegrad region}

The Visegrad Group (also known as the "Visegrad Four" or simply "V4") reflects the efforts of the countries (The Czech Republic, Hungary, Poland and Slovakia) of the Central European region to work together in a number of fields of common interest within the all-European integration [15].

In recent decades, the Visegrad Group has functioned at best as a separate geographical area or, at worst, as an object of a political and economic competition both between its founding nations as well as between the East and West. This often-divided region, with its complicated historical relationships, has witnessed various tensions, hardly making it an economic entity, which structurally exhibits a cohesive whole. The divergence in economic paths of the region was evident in its lack of a joint policy towards EU accession. However, all of this has changed in recent years [16], when the V4 countries joined the European Union. They accessed the EU in 2004 as rather weak nations economically, but with huge growth potential. With a population of above 64 million, or $13 \%$ of the EU28, the economic output of the Visegrad countries totaled only about $3.7 \%$ of that of the EU28. After 10 years of EU membership, the V4 countries have become much stronger economically and more relevant for the European Union. The economic strength of the V4 relative to the EU28 as measured by GDP has increased by one half over the last decade to $5.4 \%$ of that of the EU28. The economic relevance of the V4 has become most visible in foreign trade. The share of V4 exports relative to those of the EU28 has increased to $9.1 \%$, from $5.8 \%$ a decade ago [17].

The way in which the V4 emerged from the economic crisis brought the countries to the attention of the EU community, as a bloc which together could encourage a transformation of the European Union itself [16]. In the efforts to strengthen their position within EU, the V4 countries often present strong

\footnotetext{
${ }^{3}$ http://www.visegradforesight.itee.radom.pl. Accessed 18.11.2016
} 
opposing opinions directed against the EU policy (for example towards immigration). Certainly, the V4 countries put national sovereignty at the forefront of their priorities.

One of the tools, which is used by the V4 group to encourage mutual cooperation, is the International Visegrad Fund (IVF). The fund supports the development of cooperation in culture, scientific exchange, research, education, exchange of students and development of cross-border cooperation and promotion of tourism. The annual contributions to the fund by the governments of the Visegrad Group countries have had an increasing tendency: it rose from $€ 3$ million in 2004 to $€ 8$ million as of 2014. It allows implementing a number of joint projects (in the V4 region and the neighbouring countries) particularly in the fields of culture, environment, internal security, defence, science and education. ${ }^{4}$

When discussing the future of business of the region, it is important to shed light on the main challenges facing the V4 countries. OECD identifies these in a project that looks at the current prospects analyzing the trends in the last two decades, since the early '90s. The Going for Growth 2014 edition [18] regroups $\mathrm{OECD}$ and major non-OECD countries according to the common nature of the key challenges and gives an overview of the actions taken over the past 2 years on policy priorities identified in previous issues of the report. The groups of countries (including V4 economies) are summarized in the Table 1 below.

Czech Republic, Hungary, Poland and Slovak Republic fall into Group 2, that is countries facing high long-term unemployment, low labour force participation of specific groups and a large productivity gap.

Apart from identifying weaknesses and strengths, OECD provides policymakers with concrete reform recommendations to boost growth based on their ability to improve longterm material living standards through higher productivity and employment. Common policy challenges envisaged for V4 economies include raising productivity growth as well as addressing specific shortcomings of the labour markets, such as low internal mobility and excluded population groups. They are shown in Table 2.

Against these economic challenges, V4 economies need to move up the value chain of production, explore more possibilities in the export of services and improve the quality of institutions in order to maintain the income convergence and utilize further benefits from EU membership [17] thus contributing to the EU growth itself.

In order to support the region's position in the global value chain race [16] the V4 region needs shared visions about the future of business and shared actions combined with smart specialization policies implementation [19, 20] to take advantage from interregional opportunities and be up to international competition. Certainly, Foresight capacity building is instrumental to enabling the development and deployment of shared business strategy and growth plans in the region.

\section{Literature overview and methodological approach}

The countries in Central and Eastern Europe have a long tradition of planning at national level having been functioning for many years in the system called as "centrally planned economy". However, the mechanism of annual, medium (5 years) and longer term planning activities was hierarchically organised and it had little to do with the concept of modern Foresight [21-25]. After a decade within the EU bloc, Foresight initiatives in V4 countries show a rich and diverse picture as far as their focus, objectives, methodology, outputs and regional prevalence are concerned. Three of the four countries (CZ, HU, PL) realised their national Foresight exercises sponsored by respective governments $[15,25,26]$ and many regional and sectoral Foresight projects were executed [27-29], taking the advantage of EU structural funds. However, as evaluation of these show [30] the use of the results in policy making (for example when developing national or regional smart specialization strategies) was limited [20]. Similarly, the involvement of V4 business sector in publicly funded Foresight exercises have been remarkably low and resulted in marginal knowledge of the concept and its benefits $[13,31]$.

The undertaken research represents one of the two ${ }^{5}$ pioneering initiatives, which aim to curb futures illiteracy and increase future-sensitivity and preparedness in Visegrad region. The objective of the research is to develop and discuss alternative business futures for V4 region through the involvement of entrepreneurs and Foresight experts from Visegrad countries.

Since the aim of Foresight is to systematically explore alternative futures [33] and owing to the fact that scenario development is the most commonly used method in Foresight [34-36], thus providing a rich scenario repository, such as [37], for potential analysis, the authors have decided to make scenario-building a focal project method and learning-by-doing Foresight experience for entrepreneurs from V4 region.

There are many definitions of scenarios in publications [1, 34, 38-50]. The method was created by Herman Kahn, who borrowed the idea from film scenario and transformed the original idea adequately into the scientific convention. Since then scenario building in Foresight has become a combination 
Table 1 Country groupings according to the common nature of the most pressing challenges as identified by OECD

\begin{tabular}{|c|c|c|c|}
\hline & Countries & Main challenges & Strengths \\
\hline Group 1 & ESP, GRC, ITA, PRT, SVN & $\begin{array}{l}\text { High structural unemployment, low } \\
\text { competitiveness }\end{array}$ & Productivity levels close to average \\
\hline Group 2 & $\begin{array}{l}\text { CZE, EST, HUN, ERL, ISR, } \\
\text { POL, SVK }\end{array}$ & $\begin{array}{l}\text { Significant productivity gap, high long-term } \\
\text { unemployment, low internal mobility and } \\
\text { participation of certain groups }\end{array}$ & $\begin{array}{l}\text { Flexible wage adjustments, high percentage } \\
\text { of population with at least secondary } \\
\text { education }\end{array}$ \\
\hline Group 3 & DNK, NORM NLD, SWE & $\begin{array}{l}\text { Low average hours worked and overheated } \\
\text { housing market }\end{array}$ & $\begin{array}{l}\text { Good productivity level, above average shares } \\
\text { of population with tertiary education }\end{array}$ \\
\hline Group 4 & AUT, BEL, FIN, FRA, LUX & $\begin{array}{l}\text { Low participation of older workers and } \\
\text { persistently high unployment. }\end{array}$ & $\begin{array}{l}\text { Good productivity level, relatively high and } \\
\text { broadly-based business R\&D intensity }\end{array}$ \\
\hline Group 5 & AUS, CAN, CHE, GBR, NZL, USA & $\begin{array}{l}\text { Low productivity growth, high variance in } \\
\text { education outcomes and healthcare costs }\end{array}$ & $\begin{array}{l}\text { High investment in knowledge-based capital } \\
\text { and good quality tertiary education }\end{array}$ \\
\hline Group 6 & DEU, JPN, KOR & $\begin{array}{l}\text { Fast population ageing, low participation of } \\
\text { women, relatively weak productivity in } \\
\text { services }\end{array}$ & $\begin{array}{l}\text { High overall employment rates, strong export } \\
\text { base, including of capital goods }\end{array}$ \\
\hline Group 7 & $\begin{array}{l}\text { BRA, CHN, CHL, IDN, IND, } \\
\text { MEX, RUS, TUR, ZAF }\end{array}$ & $\begin{array}{l}\text { Widespread informality, uneven access to } \\
\text { quality education, infrastructure bottlenecks }\end{array}$ & $\begin{array}{l}\text { Strong potential for productivity catching-up, } \\
\text { fast-growing labour force }\end{array}$ \\
\hline
\end{tabular}

(Source: [18])

of mathematical and statistical methods, political analyses and management science concepts combined with creativity and imagination [51], depending on the goals and methodological aspects of the scenario process [34].

Table 2 Policy priorities for countries facing high long-term unemployment, low labour force participation of specific groups and a large productivity gap (Source: Adapted from [18], p. 22)

\begin{tabular}{|c|c|c|c|c|c|c|c|c|}
\hline \multirow[t]{3}{*}{ Policy priorities } & \multicolumn{8}{|c|}{ Countries } \\
\hline & \multicolumn{2}{|c|}{ CZE } & \multicolumn{2}{|c|}{ HUN } & \multicolumn{2}{|c|}{ POL } & \multicolumn{2}{|c|}{ SVK } \\
\hline & $\mathrm{R}^{*}$ & A & $\mathrm{R}$ & A & $\mathrm{R}$ & A & $\mathrm{R}$ & A \\
\hline \multicolumn{9}{|l|}{ Fostering stronger efficiency gains in private and public sectors } \\
\hline - Reduce public ownership and state control of business operations & & & & & $\sqrt{ }$ & • & & \\
\hline - Ease firm entry and administrative burden & & & $\sqrt{ }$ & & $\sqrt{ }$ & - & $\sqrt{ }$ & - \\
\hline - Reform bankruptcy procedures & & & $\sqrt{ }$ & & & & & \\
\hline \multicolumn{9}{|l|}{ Improve public sector efficiency } \\
\hline - Streamline public administration and facilitate monitoring and evaluation & & & $\sqrt{ }$ & - & & & & \\
\hline - Improve efficiency of public procurement & $\sqrt{ }$ & - & & & & & & \\
\hline - Raise effectiveness of public R\&D & $\sqrt{ }$ & & & & & & $\sqrt{ }$ & \\
\hline \multicolumn{9}{|l|}{$\begin{array}{l}\text { Promoting employment by tackling disincentives to job creation, job search } \\
\text { and labour force participation }\end{array}$} \\
\hline Reduce labour tax wedge & $\sqrt{ }$ & & $\sqrt{ }$ & - & $\sqrt{ }$ & & & \\
\hline \multicolumn{9}{|l|}{ Improve effectiveness of job search assistance } \\
\hline - Strengthen resources for job search assistance and individual follow-up & & & & & & & $\sqrt{ }$ & • \\
\hline - Better target subsidised job creation & & & & & & & $\sqrt{ }$ & \\
\hline Reduce housing-related restrictions on labour mobility & & & & & $\sqrt{ }$ & & $\sqrt{ }$ & \\
\hline Strengthen gate keeping measures for sickness and disability systems & & & & & $\sqrt{ }$ & & & \\
\hline \multicolumn{9}{|l|}{ Boost labour force participation of women } \\
\hline - Reduce fiscal disincentive to work for second earner and lone parent & $\sqrt{ }$ & & & & & & $\sqrt{ }$ & \\
\hline - Improve access to childcare services & $\sqrt{ }$ & & & & & & $\sqrt{ }$ & \\
\hline Reform pensions to reduce disincentive to work at older age & & & $\sqrt{ }$ & • & $\sqrt{ }$ & • & & \\
\hline \multicolumn{9}{|l|}{$\begin{array}{l}\text { Facility the development of labour force skills, competencies and more broadly, } \\
\text { human capital }\end{array}$} \\
\hline Strengthen vocational education and training & & & & & & & $\sqrt{ }$ & • \\
\hline \multicolumn{9}{|l|}{ Improve efficiency and outcomes in: } \\
\hline - Pre-school education & & & & & $\sqrt{ }$ & & $\sqrt{ }$ & \\
\hline - Primary and secondary education & $\sqrt{ }$ & & $\sqrt{ }$ & • & & & & \\
\hline - Tertiary education & $\sqrt{ }$ & & $\sqrt{ }$ & & $\sqrt{ }$ & & $\sqrt{ }$ & • \\
\hline
\end{tabular}

${ }^{*} \mathrm{R}$ stands for recommendation in that area, A stands for action taken over the horizon of the past 2 years 
Fig. 1 Combination of drivers and related scenarios. (Source: Authors based on [14])

\begin{tabular}{|c|c|c|c|c|c|c|}
\hline \multirow[b]{2}{*}{ SCENARIOS } & \multicolumn{2}{|c|}{$\begin{array}{l}\text { Business population } \\
\text { (small vs large) }\end{array}$} & \multicolumn{2}{|c|}{$\begin{array}{c}\text { Connectivity } \\
\text { global/cross-border/local } \\
\text { (integrated vs disconnected) }\end{array}$} & \multicolumn{2}{|c|}{$\begin{array}{c}\text { Policy Response } \\
\text { to Connectivity } \\
\text { ("embracing" vs "defensive") }\end{array}$} \\
\hline & F1+ & F1 - & F2+ & F2 - & $\mathbf{F 3 +}$ & F3 - \\
\hline Global Flexible Specialisation & F1+ & & $\mathrm{F} 2+$ & & $\mathrm{F} 3+$ & \\
\hline State Protectionism & & F1 - & & F2 - & & F3 - \\
\hline Niche Ecology Economy & $\mathrm{F} 1+$ & & & $\mathrm{F} 2-$ & & F3 - \\
\hline Diverse Small Economies & F1+ & & & $\mathrm{F} 2-$ & $\mathrm{F} 3+$ & \\
\hline Local Boosterism & F1+ & & $\mathrm{F} 2+$ & & & F3 - \\
\hline Global Coporate Economy & & F1 - & $\mathrm{F} 2+$ & & F3+ & \\
\hline Strategic State Support & & F1 - & $\mathrm{F} 2+$ & & & F3 - \\
\hline Corporate State \& Fiefdoms & & F1 - & & $\mathrm{F} 2-$ & $\mathrm{F} 3+$ & \\
\hline
\end{tabular}

A comprehensive definition, which covers many characteristics proposed by others, is the one of [34]: Scenarios are consistent and coherent descriptions of alternative hypothetical futures that reflect different perspectives on past, present, and future developments, which can serve as the basis for action.

The method aims at presenting the possible, probable and preferable future visions and directions of development for a given country, region, organisation, or even technology. Due to their flexibility and capacity, scenarios can be applied in numerous areas, e.g. strategic management, environmental assessments for public policy, technological Foresight, etc. [34, 52]. The authors decided to blend two approaches to futures thinking via development of scenarios:

- The first - a macro perspective approach, which is about developing scenarios that relate to a specific issue or condition rather than to a particular organisation. Scenarios developed in this way provide a future context for actors and organisations with the intention to informing management and decision in the smaller business [14].

- The second- a micro perspective approach focuses on scenarios as a planning and organisational learning tool or method, where individuals (company representatives) are participants in the exercise and recipients of the outcome [50].

In addressing the first - macro perspective - approach the authors have chosen to follow the methodology proposed by [14], who opted to use counterfactual thinking as a means of developing scenarios and based his analyses on the combinations of three key drivers of future economic and business activity. This allowed testing the so developed scenarios using datasets that assessed each key driver in the context of the current economy and allowed to match the four Visegrad countries with the scenarios. This part was carried out via desk research.
Fig. 2 The framework of possible business scenarios. (Source: [14], p. 784)

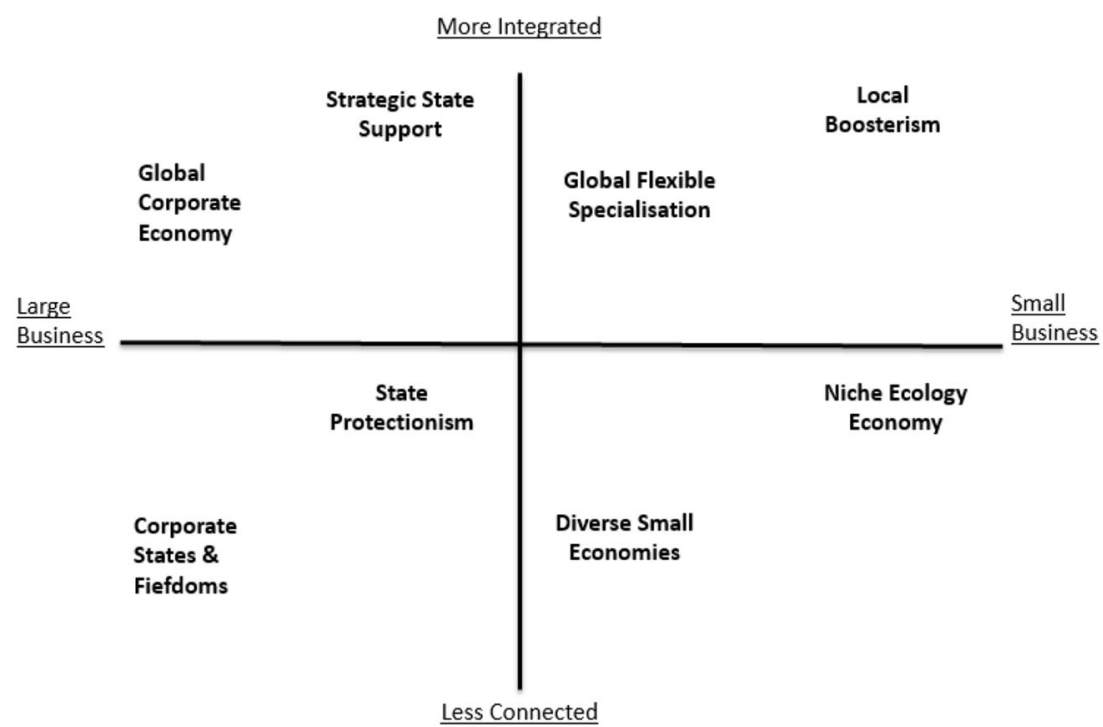


Fig. 3 Prevalence of SMEs in V4 economies, as \% share of total no of companies. (Source: Authors based on: OECD and national statistical offices databases). http://www.insme.org/files/126; http://www.oecd-ilibrary.

org/industry-and-

services/entrepreneurship-at-aglance-2014 entrepreneur_aag2014-en. Accessed 18.11.2016

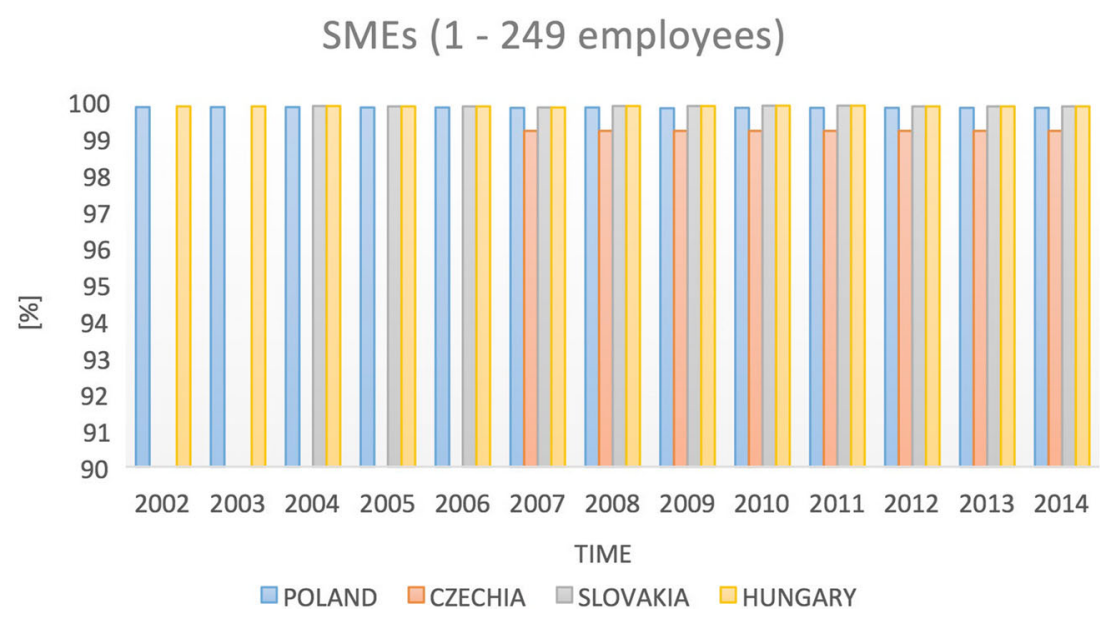

Whereas in the second - micro perspective - approach, the authors followed a more intuitive logic, which is assumed to be a standard method in the building of scenarios [48]. In the literature it is described (synonymously) as two-dimensional matrix, scenario-axes technique, four-quadrant scenarios [34, 49]. The technique seeks to identify two key driving forces of the highest importance and impact on the development of the issue, region, or organisation under research. The two key factors are then plotted on two axes, constructing four scenario quadrants - each representing a different perspective on how the future may unfold. The authors have chosen to introduce company representatives to STEEPVL analysis to help them identify and elicit key driving forces around which individual companies' scenarios were built. This part was carried out during the practical scenario workshop.

\section{Results}

As described above, the research was divided into two phases: a desk research, which addressed the macroperspective; and a scenario workshop, which addressed the micro perspective in the building of scenarios.

\section{A macro perspective - possible development scenarios of V4 economies}

The framework for business scenarios was provided by the analysis of the three main drivers, which according to [14] shape the nature of the future economy. The drivers included:

- The share of economic activity between large and small enterprises;

- The extent of connectivity in the economy, both nationally and globally;

- Response to connectivity, which considers the responses by the key economical and political actors to levels of integration and disconnection.

By applying counterfactual thinking, binary alternatives regarding to each of the three drivers were formulated. These were [14]:

- Business population: domination of small business economy or large business economy;

- Connectivity: high levels of economic integration and business connectivity or fragmentation and isolation combined with a lack of connectivity between businesses;
Fig. 4 Prevalence of micro enterprises in V4 economies, as \% share of total no of companies. (Source: Authors based on: OECD and national statistical offices databases). http://www. insme.org/files/126; http:/www. oecd-ilibrary.org/industry-andservices/entrepreneurship-at-aglance-2014_entrepreneur_aag2014-en. Accessed 18.11.2016
Micro Enterprises (<9 employees)

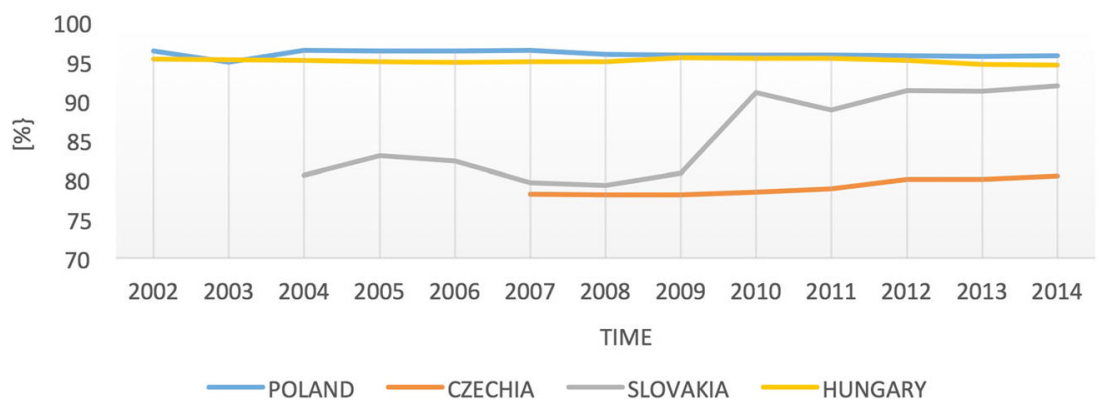


Fig. 5 Foreign direct investment (FDI) in V4 economies, net inflows (\% of GDP). (Source: Authors based on Worldbank). http://data.worldbank. org/indicator/BX.KLT.DINV.

WD.GD.ZS . Accessed

18.11.2016

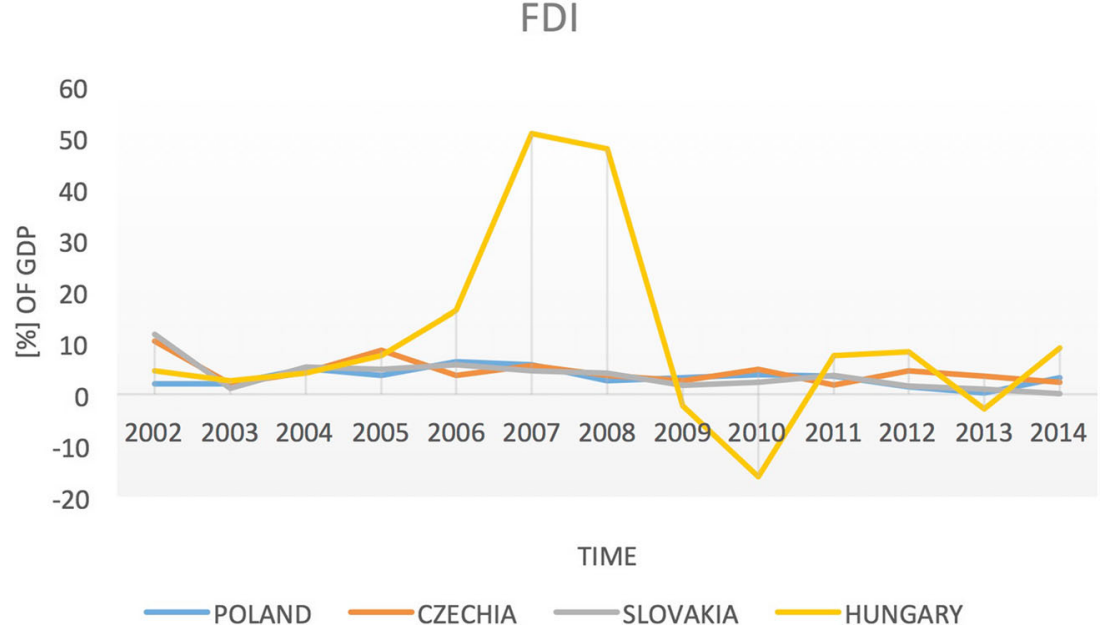

- Response to connectivity: embracing approaches or defensive reaction to future forms of connectivity.

The combination of the above drivers' alternatives resulted in eight different scenarios (Figs. 1 and 2).

Each scenario is based on the combination of the two alternatives of the three drivers (as explained in [14]). The model combination of drivers for each scenario is as follows: driver F1 [small business (+) or large business (-)] plus driver F2 [integrated economy $(+)$ or disconnected economy $(-)$ ] plus driver F3 [embracing connectivity $(+)$ or defensive towards connectivity $(-)]$.

The resulting scenarios from the above model combination are the following:

- Scenario 1: Global Flexible Specialisation: small business domination $(\mathrm{F} 1+)$; more integrated economy $(\mathrm{F} 2+)$; policy and business embracing connectivity $(\mathrm{F} 3+)$;

- Scenario 2: State Protectionism: large business domination (F1-); less integrated economy (F2-); policy and business defensive towards connectivity (F3-);

- Scenario 3: Niche Ecology Economy: small business domination (F1+); less integrated economy (F2-); policy and business defensive towards connectivity (F3-);

- Scenario 4: Diverse Small Economies: small business domination (F1+); less integrated economy (F2-); policy and business embracing connectivity (F3+);

- Scenario 5: Local Boosterism: small business domination (F1+); more integrated economy (F2+); policy and business defensive towards connectivity (F3-);

- Scenario 6: Global Corporate Economy: large business domination (F1-); more integrated economy (F2+); policy and business embracing connectivity (F3+);

- Scenario 7: Strategic State Support: large business domination (F1-); more integrated economy (F2+); policy and business defensive towards connectivity (F3-);
- Scenario 8: Corporate State and Fiefdoms: large business domination (F1-); less integrated economy (F2-); policy and business embracing connectivity (F3+).

The eight scenarios represent alternative, and significantly different possible economic futures. However, they do not represent a preferred, undesirable or business as usual future per se. Instead, the scenarios can be considered possible circumstances that will have both positive and negative effects, implications and outcomes. They represent a range of possible contexts and environments within which businesses may find themselves [14].

In order to link the economies of the Visegrad region with the so-identified scenarios, the authors carried out the analysis of the individual country figures, which represented the three key drivers through specific economic indicators in the following format:

- Key driver 1 (business population) was described by the indicators: Prevalence of SMEs in national economy; Prevalence of micro enterprises in national economy ${ }^{6}$;

- Key drivers 2 and 3 (connectivity in the economy and policy and business response towards connectivity) were described by the two indicators: Net difference between exports and imports, as an overall percentage of $G D P^{7}$; and Foreign direct investment (FDI), as net inflows (\% of GDP $)^{8}$

The results of quantitative data analysis for V4 countries are shown in Figs. 3, 4, 5, and 6.

The conclusions from the data analysis supported with the latest literature findings on the topic are the following:

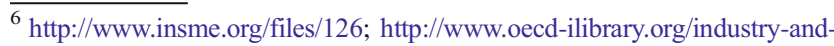
services/entrepreneurship-at-a-glance-2014_entrepreneur_aag-2014-en . Accessed 18.11.2016

${ }^{7}$ http://data.worldbank.org/indicator/NE.RSB.GNFS.ZS. Accessed 18.11.2016

${ }^{8}$ http://data.worldbank.org/indicator/BX.KLT.DINV.WD.GD.ZS . Accessed 18.11.2016
} 
Fig. 6 Net difference between exports and imports in V4 economies, as an overall percentage of GDP. Source: Authors based on Worldbank). http://data.worldbank. org/indicator/NE.RSB.GNFS.ZS. Accessed 18.11.2016
TRADE BALANCE

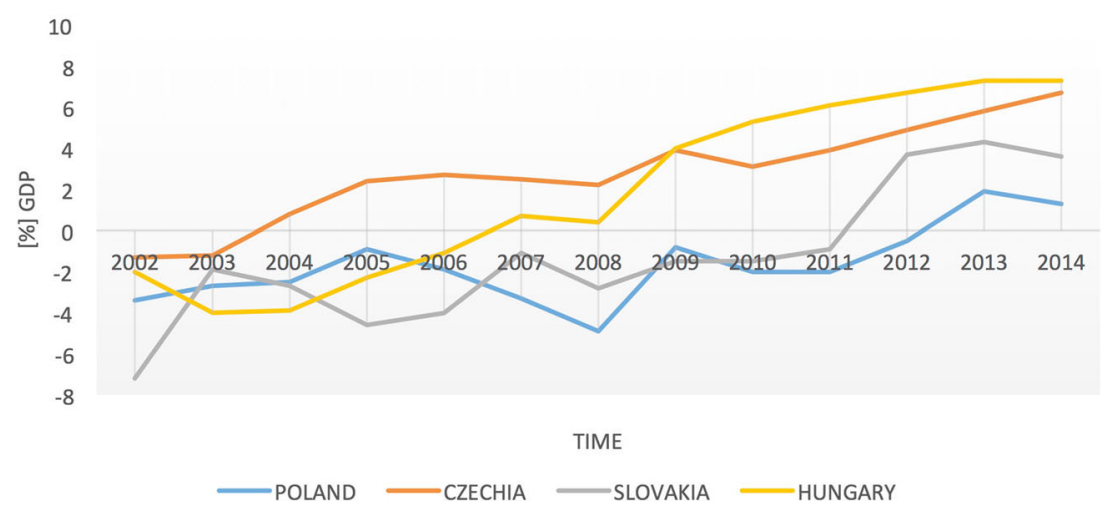

- Since economic transformation in Visegrad Countries, SMEs have been important for their economic development and they have been dominating in the economic structure of V4 countries, both in the total number and share in economic value creation. However, their role in national economies and internationalisation paths differ from country to country. The key characteristic of Czech's SMEs is their share in international supply chains, which results in sectorial shift towards manufacturing. The share of Hungarian high-tech manufacturing firms and knowledge-intensive services provided by SMEs is only marginally lower than in the EU as a whole. The value added that is generated by Polish SMEs is significantly lower, which is the evidence of their lower productivity and a concentration of Polish micro enterprises in low value-added sectors. The performance of Polish SMEs in the knowledge-intensive service sector is also below the EU average. Slovakia's performance in the single market area is higher than the EU average. Also its SMEs are more active than average within the single market [53].

- Eastern enlargement of the European Union was accompanied by an expansion of industrial capacities on the part of multinational corporations in the Visegrad Four countries [54]. Foreign direct investment (FDI) has been increasing rapidly especially in Hungary. However, as a result of the global and EU financial crisis and slowdown, Hungarian economy experienced a severe recession, as the growth rate was a negative $6.8 \%$. The lingering impact of the economic crisis for Hungary has been exacerbated by more selective and restrictive policies on FDI and a slowed pace of economic liberalization. Domestic economic problems and high budget deficits and public debt, led to more restrictive fiscal policy including tax increases and the new conservative government in 2010 has shifted toward more state regulation and intervention. The result has been mixed messages to foreign firms and investors creating policy uncertainty and an emerging image problem $[55,56]$.
- FDI has apparently lost the growth-driving role in CEE that it had before the crisis. Multinationals are no longer rapidly expanding their production capacities, but have entered a consolidation stage of expanding profitable operations through reinvestment. The main challenge at this stage is to upgrade the ways in which affiliates are integrated in European and global production networks and also to increase local income and investment from participation in these value chains [54].

- All Visegrad countries have seen a positive development in terms of international exchange of goods - a steady increase during the analysed period with an exception of 2008. As far as the trade balance is concerned, the Czech economy has the leading surplus position. The same development is apparent (with some time delays) in Hungary and lately also in Slovakia. Polish situation is different. As the largest exporter and importer, given its size, Polish economy experiences long-term deficits, since its export is less connected to inflow of export oriented direct investment [57].

In 2005, from among of four group of countries identified by Atherton, the two analysed Visegrad economies (Poland and Czech Republic) were classified into:

- Countries with low levels of connection, that is: economies with low levels of international investment and trading performance and relatively high or average small business population. As suggested by the data up to 2005 analysed by the authors, it is also the group into which Hungary and Slovakia fall into.

These characteristics reflected the conditions of Diverse Small Economies scenario (scenario 4, see above) "within which small businesses dominate, but markets are less connected and business interactions more localised than globalized. (...)Embracing this future could lead to local attempts, by businesses and government, to encourage greater levels of economic activity within each economic unit. (...)The 
Fig. 7 Visegrad countries mapping against the scenario framework (2005 vs 2014+). (Source: Authors based on [14] and own calculations)

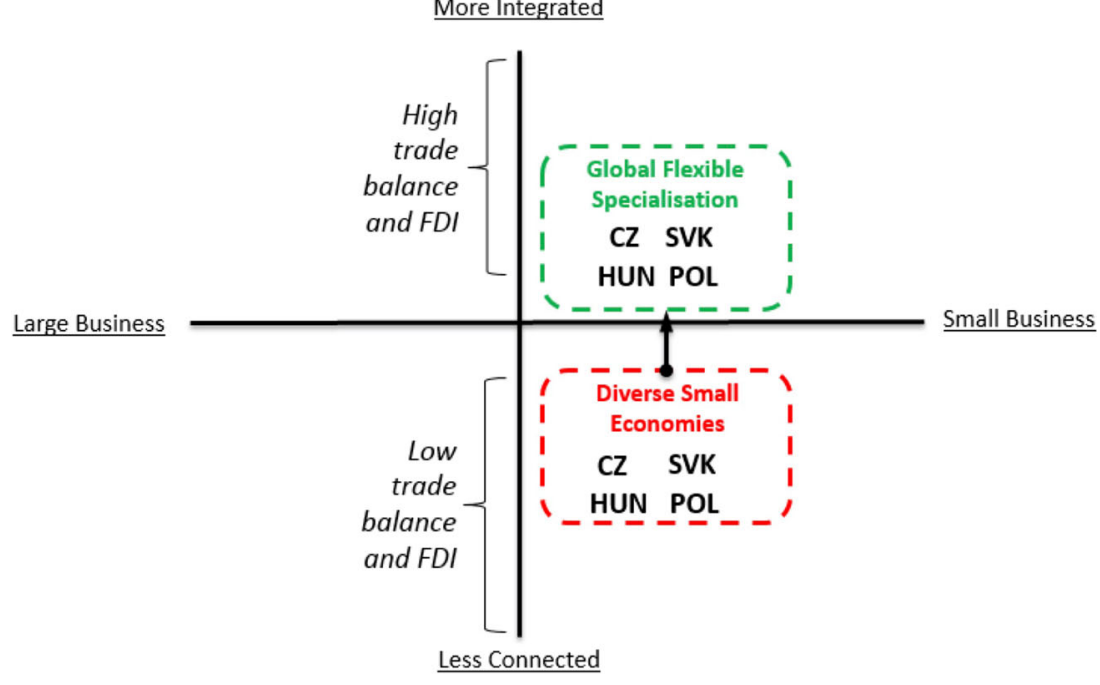

constraints of operating within localised and fixed economic areas and environments may lead to efforts to encourage cooperation and interventions to punish or minimise high levels of competition, particularly those seeking to gain short-term or non-sustainable competitive advantage over other businesses. This scenario may also lead to greater awareness of the need for sustainability of resources [14]."

However, after data update, which shows increased dynamics of integration of V4 countries with the international economy (as data related to trade balance and FDI show), the authors claim that after 10 years they are more to be falling into the Global Flexible Specialisation scenario (sceanrio 1, see above) (Fig. 7). In this scenario "a future economy is dominated by small businesses, and hence by small business 'ways of doing business', where markets are connected and small businesses trade without regard to administrative, political or market boundaries. (...) Such a scenario is likely to be based on the emergence of clusters of international and global competitiveness that deploy local and embedded relations and trust to gain advantage. It will also result in high levels of product and service differentiation, and hence high levels of consumer choice and purchasing power (due to 'seller power' being dispersed amongst many businesses, mainly small, in many locations). Global flexible specialisation is also likely to lead to high levels of investment, by businesses and probably also by governments and multi-lateral institutions, in communications and mobility infrastructure in order to reduce transaction costs and so take advantage of the internationalised nature of business interaction and the diversity of choice, location and activity [14]."

Figure 7 illustrates the transition of V4 economies from DSE scenario towards GFS scenario based on the results of updated quantitative data analysis for Visegrad countries plotted on a scenario matrix, where:
- The X-axis portrays business population: domination of SMEs vs large enterprises;

- The y-axis portrays the connectivity in the economy: more vs less integrated in terms of trade balance and FDI.

In this phase, the added value from the executed research stems from: extending the original time span of analyses (from 2005 to 2014); including two additional countries into the analyses (Hungary and Slovakia) and thus updating the business scenarios for the whole V4 region.

\section{A micro perspective - possible development scenarios of individual V4-based companies}

At a visioning workshop the authors of the paper together with representatives of V4 companies aimed to answer the question pertaining from the above analyses, that is: What's the future of a company based inV4 region, which is: connected, integrated and small-business driven?

The key workshop activities included:

- Brief introductory presentation about scenario method (incl. case studies);

- Presentation of scenarios developed with Atherton's methodology (incl. data for the four project countries);

- Development of scenarios from a perspective of an individual V4-based company.

The expert-based scenario workshop methodology was aimed to complement (and enrich) the preceding more quantitative scenario building approach. The participants of the workshop were divided into three groups comprising entrepreneurs and Foresight experts. After an introduction to 
Fig. 8 The detailed methodology of the scenario workshop. (Source: Authors)
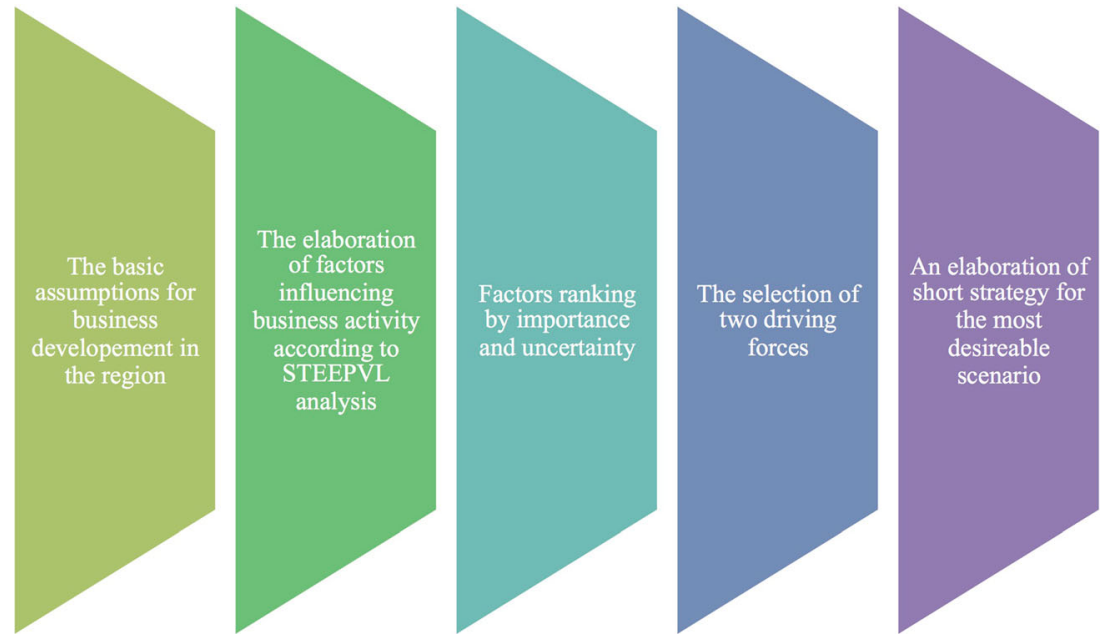

In the next stage, because of the time constraints, they

scenario-axes technique, their task was to elaborate four scenarios of business entities located in V4 region. The methodology for the workshop was based on the intuitive logic school [58] and comprised five research tasks (Fig. 8).

First of all, the experts were asked to decide on the sector they operate in, the size of the company, the region of their business activity, technology and products they develop. The experts chose the following sectors for the scenario analysis: machine industry, transportation in V4, 3D printing. For the further analysis, the authors of the article have selected 3D printing. The selection of the case to be described has been based on the criteria of data completeness. The basic assumptions for 3D printing company are presented in Table 3 .

The experts agreed on the name of the company, namely "DDD" service provider. They assumed that the company would represent SMEs sector with the size of 50 people employed. For the company's location they selected south Poland, at the same time they agreed that it competed globally (accordingly to Global Flexible Specialisation scenario). The experts assumed that the company would develop printing (plastic, metal and powder technology) and would act as a service provider on the market.

As the next step, they brainstormed factors that would shape their business activity according to STEEPVL analysis. They were asked to submit the factors within each of the STEEPVL category. The whole research process was moderated by Foresight researchers. The experts were also inspired by the pictures elaborated within CIMULACT project ${ }^{9}$.

All in all, the experts representing 3D printing group submitted and discussed 57 factors influencing their business activity (including 4 social factors, 7 technological factors, 10 economic factors, 7 ecological factors, 11 political factors, 9 factors related to values and 9 legal factors). The complete list of STEEPVL factors is presented in the annex 1.

\footnotetext{
${ }^{9}$ http://www.cimulact.eu. Accessed 18.11.2016
}

selected the two most important factors in each category and ranked them by importance and predictability. As a result of this activity, they came up with two driving forces shaping 3D printing business namely: the pace of technologies' development and their costs of growth. The extreme values of the driving forces, i.e. disruptive technologies vs. slow pace of technological development and high costs versus low costs of technological development constituted the framework for four alternative scenarios of $3 \mathrm{D}$ printing development. The basic characteristics of the scenarios are presented in Fig. 9 .

The experts agreed that the most desirable scenario of 3D printing development is a scenario, which they named Breakthrough New Paradigm Scenario described as the low costs and fast pace of technologies development. In the experts' opinion, this is a scenario characterized by such qualities as more "efficient" production, more customization options, growing competition on price, loss of traditional professions, more demands from niche markets, lower public support and higher private one.

In the final stage of scenario exercise, the experts were asked to develop a strategy for the desirable scenario development. The experts in the group agreed to focus their strategy on six dimensions such as i) marketing and communication, (ii) education and training, (iii) re-organising structure and processes, (iv) re-pricing existing customers, (v) R\&D activities and (vi) foresight activities. They also submitted some activities that would support strategy implementation in the

Table 3 The basic assumptions for the activity of 3D printing company (Source: Authors' study based on FOR_V4 workshop results)

\begin{tabular}{ll}
\hline The name of the company & "DDD" service provider \\
Size & 50 people \\
Region & global/international, located in south Poland \\
Technology & printing: plastic, metal, powder \\
Products & service provider \\
\hline
\end{tabular}


Fig. 9 Four scenarios od 3D printing technology development. (Source: Authors' study based on FOR_V4 workshop results)

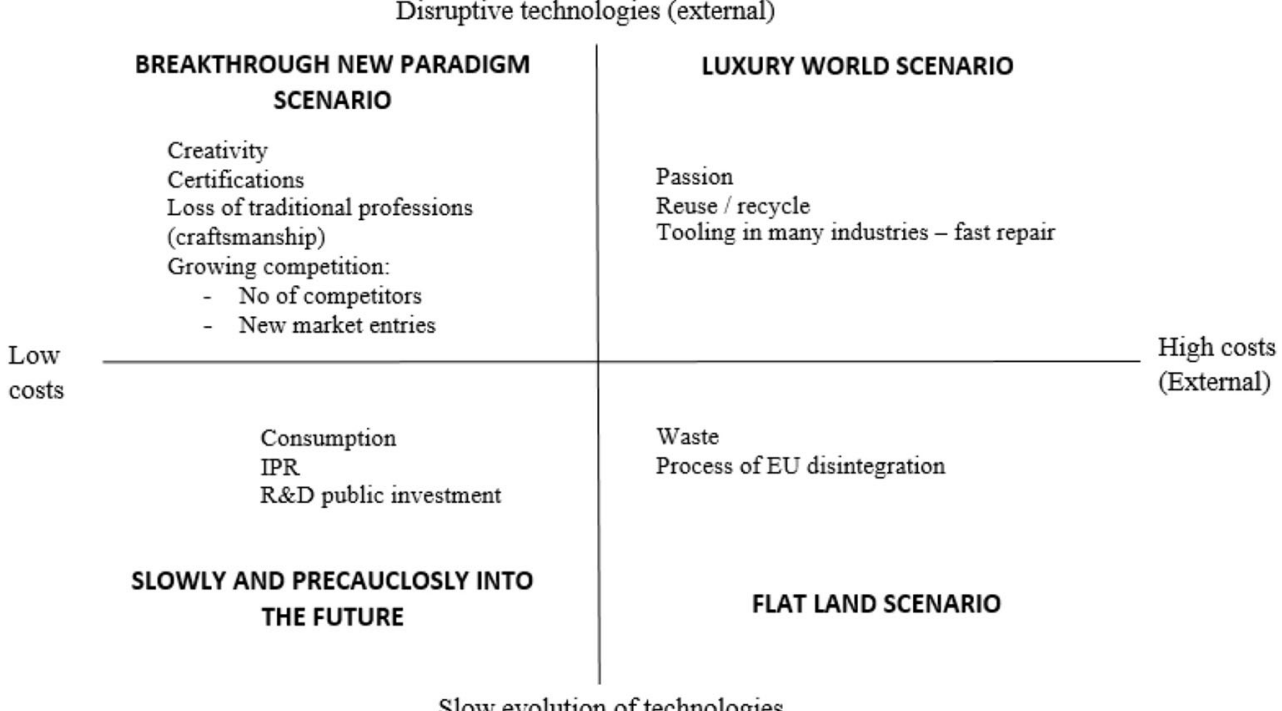

Slow evolution of technologies

The summary of the undertaken research is shown in the Table 4.

The key features of the research is the combination of macro and micro perspectives, which resulted in the update of scenarios of V4 region and development of individual scenarios of V4-based companies.

First of all, the combined macro- and micro- approach used in FOR_V4 project provided the uncomplicated way to make entrepreneurs familiar with both quantitative and qualitative methods of building scenarios.

The approach can easily be replicated by Foresight researchers and practitioners from other countries who, similarly to the authors of the paper, wish to use Atherton's [14] "externally generated" scenarios as a starting point when discussing future of business in

Table 4 Overview of the research undertaken (Source: Authors)

\begin{tabular}{|c|c|c|c|c|}
\hline General aim & $\begin{array}{l}\text { Methodological } \\
\text { assumption }\end{array}$ & Methods & $\begin{array}{l}\text { Achieved } \\
\text { added value }\end{array}$ & \\
\hline \multirow[t]{2}{*}{$\begin{array}{l}\text { Develop and discuss } \\
\text { alternative business } \\
\text { futures for V4 region }\end{array}$} & \multirow[t]{2}{*}{$\begin{array}{l}\text { Scenario building method } \\
\text { encompassing } \\
\text { quantitative } \\
\text { and qualitative } \\
\text { foresight approaches }\end{array}$} & $\begin{array}{l}\text { Desk research } \\
\text { Quantitative scenario } \\
\text { approach as in [14] }\end{array}$ & $\begin{array}{l}\text {-Data update and new V4 } \\
\text { economies analysed } \\
\text {-Demonstrated V4 economies } \\
\text { transition to another scenario } \\
\text { based on the updated } \\
\text { quantitative analysis } \\
\text {-Providing good starting point for } \\
\text { analyses during the following } \\
\text { scenario workshop }\end{array}$ & \multirow[t]{2}{*}{$\begin{array}{l}\text { Advancement } \\
\text { of futures } \\
\text { research in } \\
\text { V4 region }\end{array}$} \\
\hline & & $\begin{array}{l}\text { Scenario workshop } \\
\text { Intuitive logic school [58] } \\
\text { Scenario-axes technique [48] } \\
\text { STEEPVL analysis } \\
\text { supported by visual aids } \\
\text { from [http://www.cimulact.eu] }\end{array}$ & $\begin{array}{l}\text {-Possible factors influencing } \\
\text { specific business activity identified } \\
\text {-Individual V4 region-based } \\
\text { business scenarios developed } \\
\text {-Increased Futures Literacy of V4 } \\
\text { business representatives } \\
\text { participating in the workshop }\end{array}$ & \\
\hline
\end{tabular}


their countries ${ }^{10}$. By updating the quantitative drivers it is feasible to analyse the changes in the country/ scenario attribution as referenced in 2005 by [14]. In the paper such an update has been provided for Poland and Czech Republic. One may also easily expand the analysis to cover a broader range of countries, than the 20 economies' sample analysed by [14]. The paper provides original data for Hungary and Slovakia, which were not included in the original pole of countries analysed back in 2005 .

Whereas, citing the workshop participants' comments from evaluation questionnaires, the FOR_V4 scenario workshops based on structured methodology challenged experts' mental models and offered a range of hunting issues related to their business activity development. They were stressing the fact that finally they have been shown how to deal with complexity and what type of vocabulary is needed to think about the futures. The authors of the article would like to stress once again that generating scenarios allows future possibilities to be investigated in a systematic manner, thus "clarifying present action in the light of possible and desirable futures" as posited by [59]. Furthermore, it seemed that the workshop method succeeded, as the project participants were eager to engage with the scenarios and explore hypothetical futures, which depended on clarity and transparency in the process of scenario building.

By combining a more quantitative-oriented macro perspective with a more expert-oriented micro perspective of building scenarios the authors of the paper have tried to curb the well-known limitations ${ }^{11}$ [described by $34,49,61]$ of the scenario-axes technique, which was the main method of the scenario building workshop. Judging from the achieved results and taking into account the positive feedback received from the workshop participants, it seems that the method sufficiently met the goals of the project study: it revisited business scenarios for V4 region and it provided learning-by-doing foresight experience to company representatives, who are expected to experiment more with foresight in their business practice.

\footnotetext{
${ }^{10}$ As suggested in [14] p. 791: "the scenarios developed in this paper represent a starting point for future thinking within businesses".

${ }^{11}$ Some drawbacks of the scenario-axes approach [34, 60, 61] relate, for example, to the poor incorporation of discontinuities (a temporary or permanent, sometimes unexpected, break in a dominant condition caused by the interaction of events and long term processes) into studies based on the scenario-axes technique and thus hampering the scenario complexity and dynamics. Other authors [49] argue that this approach is only functional if two overwhelming driving forces can be identified. In practice, it is often assumed that the two most important "essential mechanisms" or "fundamental driving forces" can be found "out there." To overcome these drawbacks more recent approaches might also be taken into account, such as: RIMA - reflexive, interventionist multi-agent scenario practices or Futures Literacy Knowledge Laboratories [9] as more collaborative and participatory approach.
}

Open Access This article is distributed under the terms of the Creative Commons Attribution 4.0 International License (http:// creativecommons.org/licenses/by/4.0/), which permits unrestricted use, distribution, and reproduction in any medium, provided you give appropriate credit to the original author(s) and the source, provide a link to the Creative Commons license, and indicate if changes were made.

\section{References}

1. Wack P (1985) Scenarios: Uncharted Waters Ahead. Harv Bus Rev 63(5):73-89. Available at https://hbr.org/1985/09/scenariosuncharted-waters-ahead

2. de Geus A (2005) The living company - long-term thinking in a changing society. In: Burmeister K, Neef A (eds) In the long run. Oekomverlag, Munich, pp 112-122

3. Geus de A (1988) Planning as learning. Harvard Busines Review.https://hbr.org/1988/03/planning-as-learning

4. Bootz JP (2010) Strategic foresight and organizational learning: a survey and critical analysis. Technol Forecast Soc Chang 77:1588 1594

5. Major E, Asch D, Cordey-Hayes M (2001) Foresight as a core competence. Futures 33:91-107

6. Cunha MP, Palma P, Costa N (2006) Fear of foresight: knowledge and ignorance in organizational foresight. Futures 38:942-955

7. Kononiuk A, Sacio-Szymańska A (2016) Assessing the maturity level of foresight in Polish companies - a regional perspective Eur J Futures Res 3. DOI 10.1007/s40309-015-0082-9

8. Miller R (2009) No Future - how to embrace complexity and win. http://www.cybermanual.com/no-future-how-to-embracecomplexity-and-win1-riel-miller.html. Accessed 18.11.2016

9. Miller R (2015) Learning, the future, and complexity: an essay on the emergence of futures literacy. Eur J Educ 50(4). DOI: 10.1111 /ejed. 12157

10. Kuusi O, Cuhls K, Steinmüller K (2015) Quality criteria for scientific futures research. Futura 1:60-77

11. Poteralska B, Sacio-Szymańska A (2014) Evaluation of technology foresight projects. Eur J Futures Res 2:26. doi:10.1007/s40309013-0026-1

12. Bishop P, Hines A (2012) Teaching about the future. Palgrave Macmillan, UK

13. Sacio-Szymanska A (ed) (2016) Corporate roresight potential in Visegrad (V4) Countries. ITeE-PIB Press, Radom, p 1-142. Available at www.visegradforesight.itee.radom.pl

14. Atherton A (2005) A future for small business? Prospective scenarios for the development of the economy based on current policy thinking and counterfactual reasoning. Futures 37:777-794

15. Havas A (2003) Evolving foresight in a small transition economy. J Forecast 22:179-201

16. Golonka M, György L, Kruliš K, Pokrywka Ł, Vaňo V (2015) Middle-income trap in V4 countries? - Analysis and Recommendations. The Kosciuszko Institute

17. Jedlička J, Kotian J, Münz R (2014) Visegrad Four - 10 years of EU membership. Erste Group Research CEE Special Report

18. OECD Economic Policy Reforms (2014) Going for growth interim report. https://www.oecd.org/eco/growth/overview-of-structuralreform-actions-2014.pdf, p. 16. Accessed 18.11.2016

19. Kroll H (2015) Efforts to implement smart specialization in practice - leading unlike horses to the water. Eur Plan Stud 23(10):2079 2098

20. Mieszkowski K, Kardas M (2015) Facilitating an entrepreneurial discovery process for smart specialisation. The case of Poland. J Knowl Econ 6(2):357-384 
21. Georghiou L (2008) The handbook of technology foresigh: concept and practice. EdwardElgar

22. Kozłowski J (2001) Adaptation of foresight exercises in Central and Eastern European Countries. http://www.ibrarian. net/navon/paper/ADAPTATION OF FORESIGHT EXERCISES_IN_CENTRAL_AND_.pdf? paperid $=86895$. Accessed 18.11.2016

23. Nyiri L (2002) How to turn "Mobilising Regional Foresight Potential" into a structural contribution to European integration. Strata- Etan Expert Group Action, European Commission Research DG - Directorate K, Brussels. https://cordis.europa. eu/pub/foresight/docs/9-howtoturn.pdf. Accessed 18.11.2016

24. Radosevic S (2002) Regional Policy, National and Regional ForesightIn Central and European Candidate Countries Strata. Etan Expert Group Action, European Commission - Research DG - Directorate K, Brussels. https://cordis.europa. eu/pub/foresight/docs/8-regionalpolicy.pdf. Accessed 18.11.2016

25. UNIDO (2005) Technology Foresight Manual. Technology Foresight in Action. Volume 2. UNIDO Vienna

26. Havas A, Keenan M (2008) Foresight in CEE countries. In: Georghiou L, Cassingena HJ, Keenan M, Miles I, Popper R (eds) The handbook of technology foresight - concepts and practices. Edward Elgar, Cheltenham, p 287-316, http://ssrn. com/abstract $=1633062$. Accessed 18.11.2016

27. Hideg É, Nováky E, Alács P (2014) Interactive foresight on the Hungarian SMEs. Foresight, 16(4): 344-359. DOI: 10.1108/FS12-2012-0091. http://unipub.lib.uni-corvinus.hu/2286/

28. Hideg É, Nováky E, Kristóf T (2013) Hungarian educational foresight: 'Vocational Training and Future'. In: Borch K, Dingli S, Jørgensen M (eds) Participation and interaction in foresight. Dialogue, Dissemination and Visions. Edward Elgar Publishing, Northampton, pp 223-237

29. Nazarko J, Glinska U, Kononiuk A, Nazarko L (2013) Sectoral foresight in Poland: thematic and methodological analysis. Int J Foresight Innov Policy 9(1):19-38

30. Nazarko J (2012) Badanie Ewaluacyjne Projektów Foresight przeprowadzanych w Polsce. MNiSW, Warszawa

31. Gáspár J (2015) How future is being constructed in the corporate strategy-making practice? PhD Dissertation, Corvinus University of Budapest, Hungary. http://phd.lib.uni-corvinus.hu/889 /2/Gaspar Judit den.pdf. Accessed 18.11.2016

32. Bartha Z, Gordon T, Jutkiewicz P, Kladivo P, Klinec I, Kołos N, Nováček P, Szita Toth K (2016) V4 state of the future. Polish Society for Futures Studies, Warsaw. http://sofi.ptsp.pl/wpcontent/uploads/pdf/final_report.pdf. Accessed 18.11.2016

33. Martin B (1996) Technology foresight: capturing the benefits from science-related technologies. Res Eval 6(2):158-168

34. Notten P (2005) Writing on the wall: scenario development in times of discontinuity. Thela Thesis \& Dissertation.com, Amsterdam

35. Popper R (2008) How are foresight methods selected? Foresight 10(6):62-89

36. Sardar Z (2010) The namesake: futures; futures studies; futurology; futuristic; foresight - what's in a name? Futures 42(3):177-184

37. Forward Looking Analysis of Grand Societal Challenges and Innovative Policies (2013) Report trends, policies and future challenges in economic, demographic, legal, social and environmental field and their territorial dimensions. http://projects.sigma-orionis. com/flagship/wp-content/uploads/2015/03/FLAGSHIP_D1.2 v2.0_final_1Oct2013.pdf. Accessed 18.11.2016

38. Chermack TJ, Lynham SA, Ruona WEA (2001) A review of scenario planning literature. Futur Res Q

39. Fink A, Siebe A, Kuhle JP (2004) How scenarios support strategic early warning processes. Foresight 6(3):173-185

40. Godet M (1994) From anticipation to action. A handbook of strategic prospective. Unesco Publishing
41. Godet M (1997) Scenarios and strategic management. Butterworths Scientific Ltd, London

42. Godet $\mathrm{M}(2000)$ The art of scenarios and strategic planning - tools and pitfalls. Technol Forecast Soc Chang 65(1):7-17

43. Kahn H (1962) Thinking about the unthinkable. Discus Books/ Avon, New York

44. Malaska P (1985) Multiple scenario approach and strategic behaviour in European companies. Strateg Manag J 6(4):339-355

45. Porter M (1985) Competitive advantage. The Free Press, New York

46. Ringland G (1998) Scenario planning: managing for the future. Wiley, New York

47. Schoemaker PJH (1995) Scenario planning: a tool for strategic thinking. Sloan Manage Rev 36(2):25-40

48. Schwartz P (1991) The Art of the Long View: Paths to Strategic Insight for Yourself and Your Company Doubleday, New York

49. Van 't Klooster SA, Van Asselt MBA (2006) Practising the scenario-axes technique. Futures 38(1):15-30

50. van der Heijden K (1997) Scenarios: the art of strategic conversation. Wiley, New York

51. Jarva V (2014) Introduction to narrative for futures studies. J Futures Stud 18(3):5-26

52. Van Looy B, Zimmermann E, Debackere K, Veugelers R, Bouwen R (2001) Development of a Methodological Framework for Examining Science and Technology in Flanders. Raport 1. Katholieke Universiteit Leuven

53. Daszkiewicz N (2014) Small and medium-sized enterprises in visegrad countries towards internationalisation challenges in the European Union. In: Durendez A, Wach K (eds) Patterns of business internationalisation in visegrad countries - in search for regional specifics. Universidad Politécnica de Cartagena, Cartagena. http://www.visegrad.uek.krakow.p1/PDF/Cartagena2014 ch09 daszkiewicz.pdf. Accessed 18.11.2016

54. Drahokoupil J, Galgóczi B (2015) Foreign direct investment in eastern and southern European countries: still an engine of growth? In: Galgóczi B, Drahokoupil J, Bernaciak M(eds) Foreign investment in eastern and southern Europe after 2008. Still a lever of growth? ETUI. https://www.etui.org/Publications2 /Books/Foreign-investment-in-eastern-and-southern-Europe-after2008.-Still-a-lever-of-growth

55. Sass M, Kalotay K (2012) Inward FDI in Hungary and Its Policy Context, Vale-Columbia Center on Sustainable Investment Country Profile

56. Torrisi R (2015) FDI in Small EU Economies: The Case of Hungary and Slovakia. Florida: AABRI, Academic and Business Research Institute. http:/www.aabri.com/SC2015Manuscripts/SC15050.pdf. Accessed 18.11.2016

57. Taušer J, Čajka R (2014) External economic balance of Visegrad countries-quantitative analysis of empirical data. In: Durendez A, Wach K (eds) Patterns of business internationalisation in Visegrad countries -in search for regional specifics. Universidad Politécnica de Cartagena, Cartagena. http://www.visegrad.uek.krakow. p1/PDF/Cartagena2014 ch10 tauser cajka.pdf. Accessed 18.11.2016

58. Fahey L, Randall RM (1998) Learing from the future. Competitive foresight scenarios. Wiley, New York

59. Durance P, Godet M (2010) Scenario building: uses and abuses. Technol Forecast Soc Chang 77:1488-1492

60. Notten P (2006) Scenario development: a typology of Approaches. In: OECD (eds) Think scenarios, rethink education. OECD http://www.oecd.org/site/schoolingfortomorrow knowledgebase/futuresthinking/scenarios/37246431.pdf. Accessed 18.11.2016

61. Notten P, Sleegers A, Van Asselt M (2005) The future shocks: on the role of discontinuity in scenario development. Technol Forecast Soc Chang 72:175-194 